\title{
Effect of Lime Coating and Molybdenum Seed Treatment on Nodulation, Growth and Yield of Different Pulses Grown in Alfisols
}

\author{
Purbasha P. Padhi* and S.K. Pattanayak \\ Department of Soil Science and Agricultural Chemistry, College of Agriculture, OUAT, \\ Bhubaneswar - 751003, Odisha, India \\ *Corresponding author
}

\section{A B S T R A C T}

Keywords

Pulses, Yield,

Nodulation, Lime coating, Molybdenum, Rhizobium, Acid soil

Article Info

Accepted:

15 January 2018

Available Online:

10 February 2018
Unavailability of low cost pure liming material is a major constraint for pulse growth, nodulation and pod yield under acid soil condition. In this context a field experiment was conducted during summer (2016-17) in the village Haripur of Khordha district, Odisha, India to study the Effect of lime coating and molybdenum seed treatment on nodulation, growth and yield of different pulses grown in Alfisols. The results revealed that seed inoculation with Rhizobium (R) increased seed yield by $16 \%$ over no inoculation (336 kg $\mathrm{ha}^{-1}$ ) and further the yield increased by 14 per cent by combining seed inoculation of Rhizobium with lime coating of seeds. Molybdenum seed treatment @ $10 \mathrm{~g}$ sodium molybdate was capable of increasing the seed yield by 45 per cent compared over no Mo treatment. Combination of all packages, further increased the yield by 61 per cent, thereby raising the yield from $336 \mathrm{~kg} \mathrm{ha}^{-1}$ due to STD alone to $630 \mathrm{~kg} \mathrm{ha}^{-1}$ due to better nodulation along with improvement in growth and yield attributes.

\section{Introduction}

Pulses constitute an important ingredient in vegetarian diet of developing countries like India and also ensure nutritional security to the poor masses. Besides, being a rich source of protein, pulses have the capacity to fix the atmospheric nitrogen. It fixes atmospheric $\mathrm{N}_{2}$ ranging from 50-100 kg ha ${ }^{-1}$ annum $^{-1}$. However under Odisha condition it ranges from 25 to $55 \mathrm{~kg} \mathrm{ha}^{-1}$ (Pattanayak, 2016).

Among several constraints for pulse production, soil acidity is the major constraint. Acidic soil reduces nodule formation and nitrogen fixation, reduces plant flavonoid secretion. More than seventy per cent soil of Odisha is acidic, out of which more than 25 per cent need immediate liming having $\mathrm{pH}<$ 5.5 (Pattanayak and Sarkar, 2016). Again Rhizobium starvation is common in micronutrients deficient acid soil. In acidic soils ( $\mathrm{pH}<5.5)$ molybdenum availability decreases as anion adsorption to soil oxides increases (Reddy et al., 1997). It is generally accepted that legumes need more Mo than most of other plants (Mcbride, 2005) due to its key involvement in the Nitrogen-fixation process. Molybdenum is required to the Rhizobium bacteria for proper function of nitrogenase enzyme which involved in nitrogen fixation. Again molybdenum is the 
cofactor for the enzyme nitrate reductase which involved in nitrogen assimilation (Hansch and Mendel, 2009). The application of molybdenum in deficient soil encouraged nitrogen fixation and nodule formation (Rahman et al., 2008).

Liming $\left(\mathrm{CaCO}_{3}\right)$ is routinely used as longterm agricultural management practice to neutralize the acid produced in the soil and to overcome the problems associated with soil acidification. Most plants grow well at a $\mathrm{pH}$ range of 5.5-6.5 and liming is aimed to maintain the $\mathrm{pH}$ at this range. Earlier recommendation was application of lime at full rate 15-30 days before sowing. Then lime application@0.2 L.R for dicot and 0.1 L.R for monocots have been recommended for crop production (Pattnayak et al., 2011). But the effect of lime is not permanent, it needs frequent application preferably mixed with organic materials (Pattanayak and Sarkar, 2016). The pure liming material $\left(\mathrm{CaCO}_{3}\right)$ is costly, less available and not affordable by poor farmers.

To reduce the amount of liming materials and getting almost similar effect of liming, coating of seeds of green gram with lime using gum acacia (Majhi and Pattanayak, 2015) and sagoo (Pati and Pattanayak, 2016) as stickers proved to be a better option for increasing productivity, grown in acid soils.

There is tremendous scope to increase current yield potential of pulses by enhancing the nutrient availability and better plant growth through liming, incorporation of micronutrients and biofertilizers in the production system. However selection of effective combination of package of practices is a critical step. Keeping this view in mind the present study was formulated with four pulse crops like green gram, black gram, cow pea and horse gram to access the most suitable combination of Rhizobium, Mo seed treatment and lime coating of seed for maximization of growth, nodulation and pulse productivity in acid soil.

\section{Materials and Methods}

The field experiment was conducted in the village Haripur of Khordha district during summer (January 2016-17). Haripur is situated at $20^{\circ} 07^{\prime} 66^{\prime \prime} \mathrm{N}$ latitude and $85^{\circ} 42^{\prime} 81^{\prime \prime} \mathrm{E}$ longitude. The soil of the experimental field comes under the soil order of Alfisols. The four crops were selected with three replicates and each consisted of five package of practices (POPs), namely (i) Only application of soil test dose (STD) of fertilizers without seed inoculation with Rhizobium, (ii) STD + seed inoculation with Rhizobium(R), (iii) STD + seed inoculation with Rhizobium (R) + seed coated with lime $\left(\mathrm{CaCO}_{3}\right) @ 12.5 \mathrm{mg}$ seed ${ }^{-1}$ or $4 \mathrm{~kg} \mathrm{CaCO} 3$ for $25 \mathrm{~kg}$ of seed required for one hectare of land $\left(\mathrm{S}_{\mathrm{L}}\right)$, (iv) STD + seed inoculation with Rhizobium (R) + molybdenum seed treatment @ $10 \mathrm{~g}$ sodium molybdate $25 \mathrm{~kg}^{-1}$ seed required for one hectare of land (Mo), (v) Adoption of all the above packages $\left(\mathrm{STD}+\mathrm{R}+\mathrm{S}_{\mathrm{L}}+\mathrm{Mo}\right)$ with four test crops i.e. Green gram (Durga), Black gram [B-3-888 (CV.Prasad)], Cow pea [KSP145 (Kalasa)], and Horse gram having a plot size $7 \mathrm{~m}^{2}$. The experiment was laid out with Factorial Randomised Block Design with 5 (five) POPs, each replicated thrice. The treatments were allocated to different plots following the random number table of Gomez and Gomez (1976).

After thorough field preparation initial soil samples were taken to analyze the initial soil properties. The experimental soil was sandy loam in texture, extremely acidic soil reactions $\left(\mathrm{pH}_{\mathrm{w}}-4.49\right)$ with low organic carbon $(4.6 \mathrm{~g} / \mathrm{kg}$ soil), and low status for available $\mathrm{N}, \mathrm{P}, \mathrm{K}, \mathrm{S}$ and Mo $\left(0.02 \mathrm{mg} \mathrm{kg}^{-1}\right)$. Fertilizers were applied on the basis of Soil test Dose i.e. N - $\mathrm{P}_{2} \mathrm{O}_{5}$ $\mathrm{K}_{2} \mathrm{O}-\mathrm{ZnSO}_{4}$ - Borax (kg/ha) (20 - 40 - 40 - 
25 - 10) from different sources like Navaratna (20-20-0-13), SSP, MOP, Borax and Zinc sulphate along with application of farmyard Manure (FYM) @ $3 \mathrm{tha}^{-1}$.

The seeds were treated with bavistin @ $2 \mathrm{~g} \mathrm{~kg}^{-}$ 1 seed as seed treatment chemical against fungal seed borne diseases. As per treatment specificity seeds were inoculated with Rhizobium@20 g kg $\mathrm{g}^{-1}$ seed. The inoculated seeds were again coated with lime using sagoo as sticker. The water soaked sago (Tapioca root extract) was boiled in hot water to form a jelly like sticking substance and allowed to cool, before adding it to the inoculated seed (since hot water will kill the Rhizobia). It was poured in to a container containing Rhizobium inoculated seeds and powdered lime. Then rotated and shaken in a manner so that lime gets coated on each seed. Seeds were treated with sodium molybdate@10g $25 \mathrm{~kg}^{-1}$ seed either in combination with Rhizobium culture or with lime coating as per the treatment.

Yield attributes were recorded at physiological maturity stage and the seed and stover yield was recorded from net plot area of each treatment and expressed in $\mathrm{kg} \mathrm{ha}^{-1}$.

Nodules were collected from plant at initial flowering stage. Twenty four hours before sampling the crop was irrigated. Five plants were uprooted randomly by digging deeply from each plot so that roots remain unaffected. These were washed with tap water carefully and nodules were collected, counted and kept for analysis. Fresh nodules weighing $0.5 \mathrm{~g}$ were digested in concentrated sulphuric acid and nodular Nitrogen was estimated by micro Kjeldahl distillation method as described in A.O.A.C. (1960).

The chlorophyll content of the leaves was measured by portable chlorophyll meter (SPAD 502; Minolta, Japan). The soil parameters namely soil $\mathrm{pH}$, organic carbon, available nitrogen, phosphorus and potassium as well as electrical conductivity along with molybdenum status of soil was estimated by standard analytical methods (Jackson, 1973; Page, 1982; Tandon, 1999).

\section{Results and Discussion}

The four target pulse crops were green gram, black gram, cowpea and horse gram. Their productivity in the state is $476,455,746$ and $385 \mathrm{~kg} \mathrm{ha}$ respectively against the demonstrated yield of 900, 800, 1100 and 900 $\mathrm{kg} \mathrm{ha}^{-1}$. To bridge the yield gap, attempts were taken giving emphasis on liming of acid soil, seed coating with lime, supplementation of deficient nutrient (Mo) very much essential for biological $\mathrm{N}_{2}$ fixation, other essential soil nutrients and Rhizobium seed inoculation (Pattanayak, 2016; Pattanayak and Rao, 2014; Pattanayak and Sarkar, 2016; Pattanayak and Rao, 2016).

The data related to the crop growth have been presented in Figure 1 (a) green gram, (b) black gram, (c) cowpea and (d) horse gram. The data shows that all the four pulse crops grows with passage of time and achieved maximum height at flowering stage, 45 days after sowing (DAS). The relative growth rate was maximum during $1^{\text {st }} 15$ days then decreases gradually. For all crops, the growth/height increased with a decreasing rate. Among four crops cowpea crop had faster growth rate at all stages followed by black gram, green gram and horse gram. Molybdenum seed treatment had greater influence on crop growth than lime coating. However, their combined use had positive influence on crop growth. It was hypothesized that the response of plant growth to the application of Mo is more pronounced in low soil $\mathrm{pH}$ condition than in natural or high levels of pH soils (Glubiak, 2008).

The data related to leaf area of four pulse crops have been presented in Figure 2. The 
leaf area of the crops increased with increase in growing period and attended maximum at 45 days after sowing irrespective of the treatments. Crops receiving seed inoculation with Rhizobium both alone or with seed coating with lime and further treatment with Mo responded positively and expressed in increase in leaf area. Molybdenum seed treatment had visible impact on increase in leaf area, however, integrating all the packages had far greater influence on leaf area of crop. Molybdenum deficient plants exhibit poor growth and shows reduced leaf blade formation, inter-veinal mottling and chlorosis around edges and tips of older leafs (Marschner, 1995; Liu, 2002).

The data related to chlorophyll content in leaves of four pulse crops have been presented in Figure 3 (a) green gram, (b) black gram, (c) cowpea, (d) horse gram. The pulse crops recorded highest chlorophyll content in leaves at $60^{\text {th }}$ days than at $45^{\text {th }}, 30^{\text {th }}$ and 15 DAS. Among crops chlorophyll content was almost same in cowpea and green gram crops, but in black gram and horse gram it was less.

The treatments imposed at early stages of crop growth period were less effective than at later stages. The Mo treatment had greater influence on chlorophyll content than other two packages, however, when the packages were combined, the effect was more positive on chlorophyll content. As a result the crops were photosynthetically active due to imposed treatments. Factors such as macro and micro nutrients also affect the metabolic reactions in photosynthetic apparatus (Marschner, 1995). It is well established that inadequate levels of any mineral nutrient in the growth media may limit photosynthesis due to their involvement in carbohydrate synthesis (Lambers et al., 1998). Calcium $\left(\mathrm{Ca}^{2+}\right)$ and Molybdenum (Mo) are essential plant nutrients; whose role has been well documented (Marschner, 1995; White and Broadley, 2003).

\section{Nodular properties}

The data related to nodule number plant $^{-1}$ in pulse crops have been presented in Table 1 . The nodule number plant ${ }^{-1}$ under the influence of package of practices (POPs) varied between 7.0 and 21.0 lowest with horse gram and highest with cowpea receiving all the POPs. The comparison of average nodule number of crops indicated that horse gram and green gram crops were at par but black gram and cowpea crops were having significantly higher nodules per plant. Comparison of impact of POPs show that Rhizobium seed inoculation alone or combining lime coating of seed with Rhizobium inoculation, or combining liming with Mo seed treatment and all the three POPs resulted in increase in $38,77,112,128$ percent of nodules compared to 8 numbers without any POP. Subasinghe et al., (2003) registered enhanced cowpea growth and nodulation with molybdenum containing micronutrients and Rhizobium inoculation.

The fresh weight of nodules under the influence of POPs ranged from 200 to $506 \mathrm{mg}$ plant $^{-1}$, lowest with green gram without any POP and highest with all POPs in the same crop. Comparison of average nodule weight per plant among four crops indicated that lowest nodule weight recorded with horse gram and significantly higher with other three crops. Among these three crops nodule number did not differ significantly.

The POPs had significant influence on weight of nodules in different pulse crops. Studies by Lucrecia et al., (1987) demonstrated that supply of $\mathrm{Ca}^{2+}$ through lime significantly increased both nodule weight and plant productivity in Pirulgaris.

The nodule $\mathrm{N}$ in four different pulse crops (Table 1) under the influence of POPs varied between 0.90 and 2.8 per cent, lowest with cowpea and highest with horse gram. 
Table.1 Nodular properties of pulse crops under the influence of POPs

\begin{tabular}{|c|c|c|c|c|c|c|c|c|c|c|c|c|}
\hline \multirow{2}{*}{$\begin{array}{ll} & \text { POPs } \\
\text { Crops } & \end{array}$} & $-\mathbf{R}$ & $+\mathbf{R}$ & $\mathbf{R}+\mathbf{S}_{\mathbf{L}}$ & R+Mo & $\mathrm{R}+\mathrm{S}_{\mathrm{L}}+\mathrm{Mo}$ & Mean & $-\mathbf{R}$ & $+\mathbf{R}$ & $\mathbf{R}+\mathbf{S}_{\mathbf{L}}$ & R+Mo & $\mathrm{R}+\mathrm{S}_{\mathrm{L}}+\mathrm{Mo}$ & Mean \\
\hline & \multicolumn{6}{|c|}{ Number of nodules/plant } & \multicolumn{6}{|c|}{ Nodule weight (mg/plant) under the influence of POPS } \\
\hline Green gram & 8.0 & 10.0 & 13.0 & 15.0 & 16.0 & 12.4 & 200.0 & 303.0 & 396.0 & 520.0 & 506.0 & 385.0 \\
\hline Black gram & 9.0 & 12.0 & 15.0 & 18.0 & 20.0 & 14.8 & 233.0 & 341.0 & 407.0 & 469.0 & 475.0 & 385.0 \\
\hline Cowpea & 7.0 & 8.0 & 14.0 & 18.0 & 21.0 & 13.6 & 209.6 & 309.0 & 390.0 & 550.0 & 452.0 & 382.1 \\
\hline Horse gram & 7.0 & 11.0 & 13.0 & 15.0 & 14.0 & 12.0 & 212.0 & 375.0 & 390.0 & 420.0 & 432.0 & 365.8 \\
\hline \multirow[t]{2}{*}{ Mean } & 7.7 & 10.2 & 13.5 & 16.5 & 17.5 & & 213.6 & 332.0 & 395.7 & 489.7 & 466.2 & \\
\hline & Crop & POPs & C x POPs & & & & Crop & POPs & C x POPs & & & \\
\hline $\mathrm{SE}(\mathrm{m}) \pm$ & 0.38 & 0.4 & 0.8 & & & & 1.5 & 1.7 & 3.5 & & & \\
\hline $\operatorname{LSD}(p=0.05)$ & 1.1 & 1.2 & 2.4 & & & & 4.5 & 5.0 & 10.1 & & & \\
\hline \multirow[t]{2}{*}{$\mathrm{CV}(\%)$} & & & 11.3 & & & & & & 1.6 & & & \\
\hline & \multicolumn{6}{|c|}{ Nodule nitrogen $(\%)$ under the influence of POPS } & \multicolumn{6}{|c|}{ Nodule nitrogen (mg/plant) under the influence of POPs } \\
\hline Green gram & 1.1 & 1.2 & 1.3 & 2.6 & 2.3 & 1.7 & 2.3 & 3.7 & 5.2 & 11.9 & 12.2 & 7.0 \\
\hline Black gram & 1.0 & 1.1 & 1.9 & 2.0 & 2.1 & 1.6 & 2.4 & 3.9 & 7.7 & 9.1 & 10.1 & 6.6 \\
\hline Cowpea & 0.9 & 1.3 & 1.7 & 1.9 & 2.0 & 1.5 & 2.4 & 4.0 & 6.4 & 10.4 & 8.9 & 6.4 \\
\hline Horse gram & 1.0 & 1.3 & 1.4 & 2.6 & 2.8 & 1.8 & 2.1 & 4.9 & 5.5 & 10.6 & 11.8 & 7.0 \\
\hline \multirow[t]{2}{*}{ Mean } & 1.0 & $1.2(21)$ & $1.5(25)$ & $2.2(83)$ & $2.3(87)$ & & 2.3 & $4.1(78)$ & $6.2(50)$ & $10.5(156)$ & $10.8(163)$ & \\
\hline & Crop & POPs & C x POPs & & & & Crop & POPs & Cx POPs & & & \\
\hline $\mathrm{SE}(\mathrm{m}) \pm$ & 0.03 & 0.03 & 0.07 & & & & 0.17 & 0.19 & 0.39 & & & \\
\hline $\operatorname{LSD}(p=0.05)$ & 0.10 & 0.11 & 0.2 & & & & 0.50 & 0.56 & 1.1 & & & \\
\hline CV $(\%)$ & & & 8.0 & & & & & & 9.9 & & & \\
\hline
\end{tabular}

() \% nitrogen increase over Rhizobium seed inoculation. 
Table.2 Green gram equivalent yield $\left(\mathrm{kg} \mathrm{ha}^{-1}\right)$ of pulse crops as influenced by liming, Rhizobium inoculation of seed and molybdenum seed treatment

\begin{tabular}{|c|c|c|c|c|c|c|}
\hline${ }_{\text {Crops }}$ POPs & $-\mathbf{R}$ & $+\mathbf{R}$ & $\mathbf{R}+\mathbf{S}_{\mathrm{L}}$ & R+Mo & $\mathrm{R}+\mathrm{S}_{\mathrm{L}}+\mathrm{Mo}$ & Mean \\
\hline Green gram & 337.3 & 388.7 & 465.3 & 606.6 & 683.6 & 496.3 \\
\hline Black gram & 335.0 & 344.0 & 413.6 & 647.0 & 719.3 & 491.8 \\
\hline Cowpea & 431.6 & 568.0 & 620.0 & 701.3 & 763.6 & 616.9 \\
\hline Horse gram & 240.0 & 264.0 & 286.0 & 310.0 & 352.6 & 290.5 \\
\hline \multirow[t]{2}{*}{ Mean } & 336.0 & 391.1(16) & $446.2(14)$ & $566.2(45)$ & $629.8(61)$ & \\
\hline & Crop & POPs & C x POPs & & & \\
\hline $\mathrm{SE}(\mathrm{m}) \pm$ & 12.3 & 13.7 & 27.5 & & & \\
\hline $\operatorname{LSD}(p=0.05)$ & 35.2 & 39.4 & 78.8 & & & \\
\hline CV (\%) & & & 10.0 & & & \\
\hline
\end{tabular}

[*Data in the parenthesis shows the percentage increase in yield]

Fig.1 Change in plant height $(\mathrm{cm})$ under the influence of seed coating with lime, inoculation with Rhizobium and treatment with Molybdenum

(a) Green gram

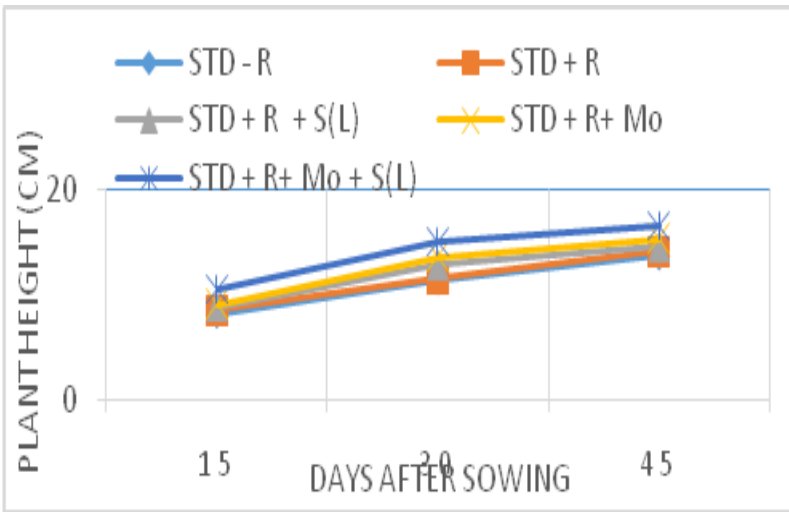

(c) Cow pea

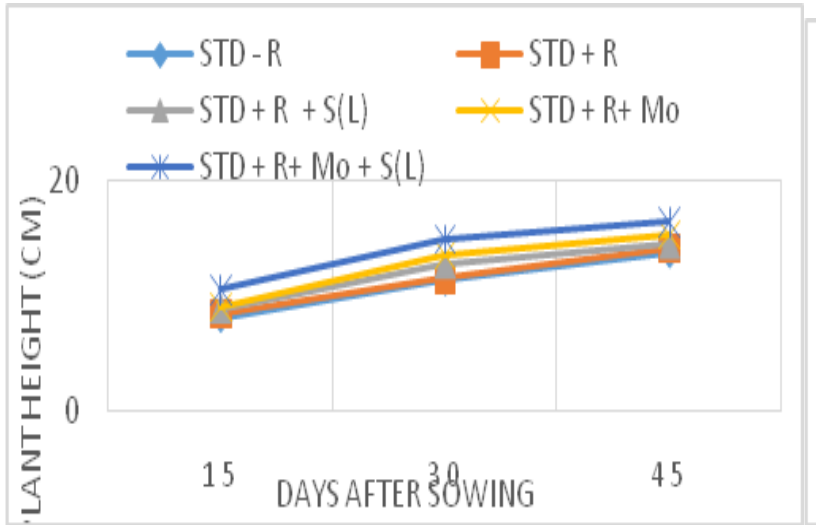

(b) Black gram

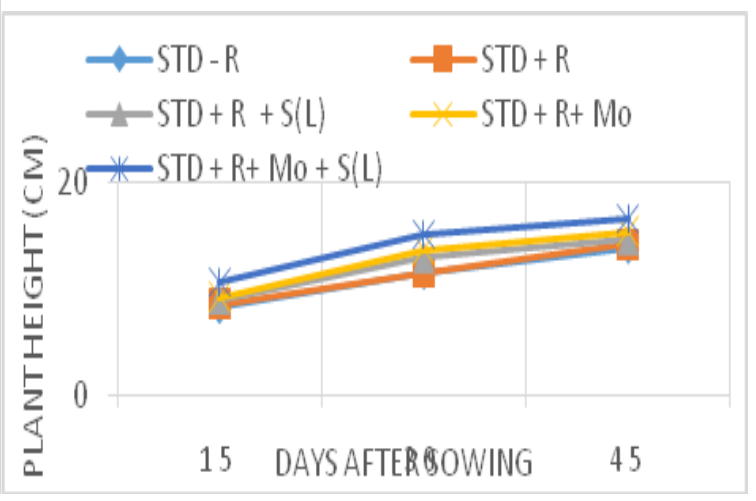

(d) Horse gram

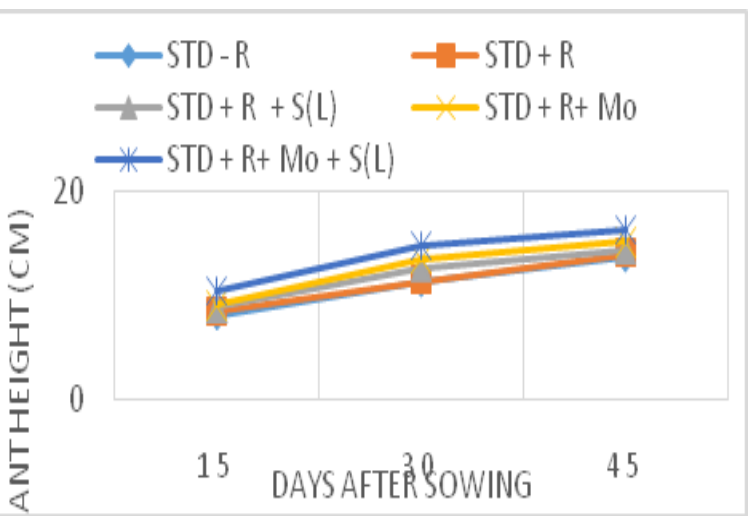


Fig.2 Leaf area of crops under the influence of seed coating with lime, inoculation with Rhizobium and treatment with Molybdenum

(a) Green gram

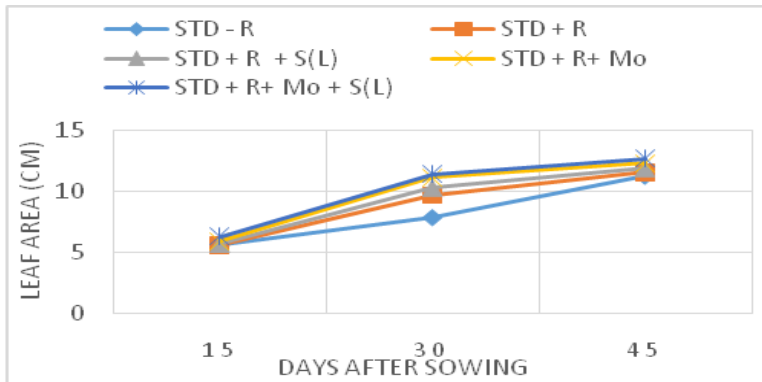

(c) Cow pea

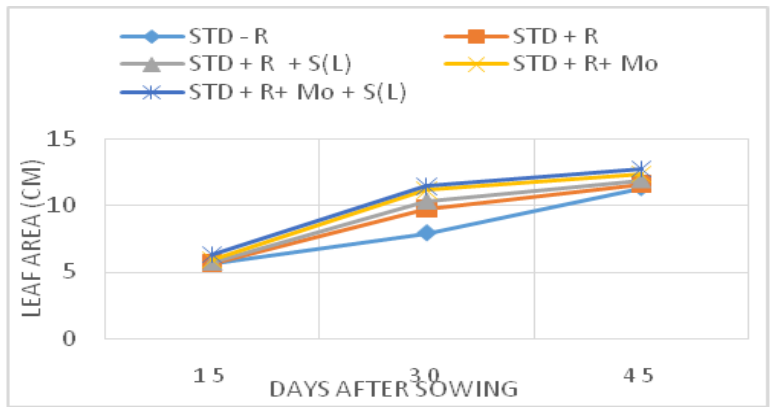

(b) Black gram

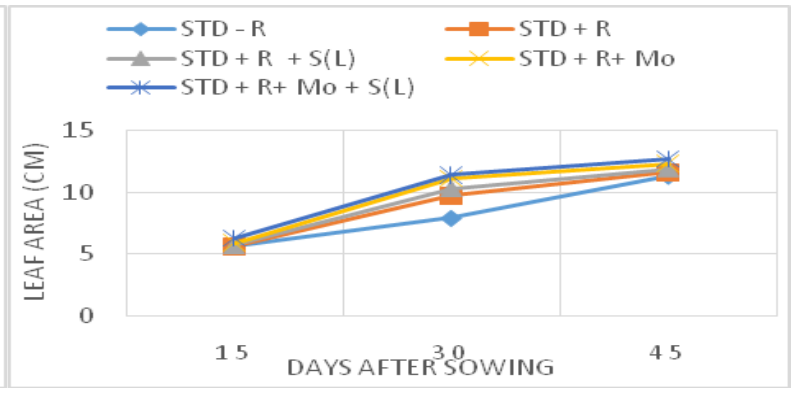

(d) Horse gram

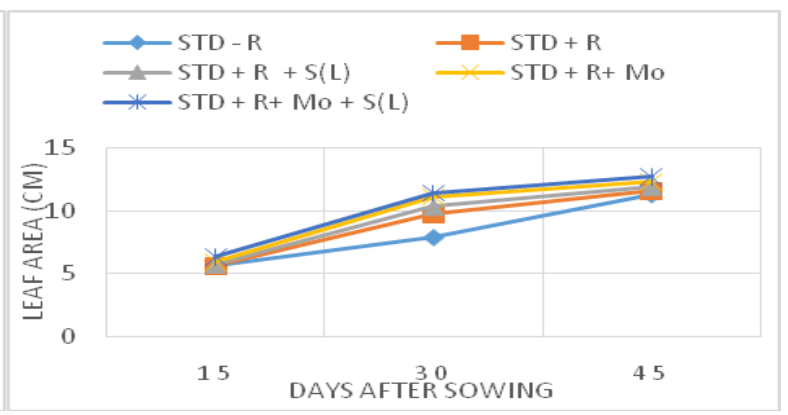

Fig.3 Chlorophyll content in leaf (SPAD value) under the influence of lime coating of seeds and inoculation with Rhizobium and treatment with molybdenum

(a) Green gram

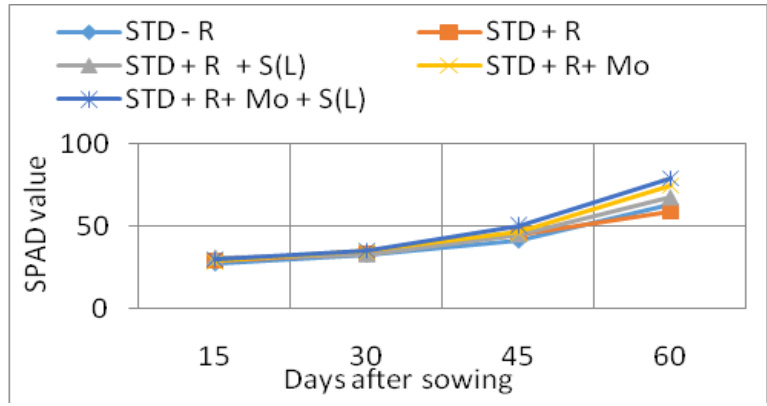

(c) Cow pea

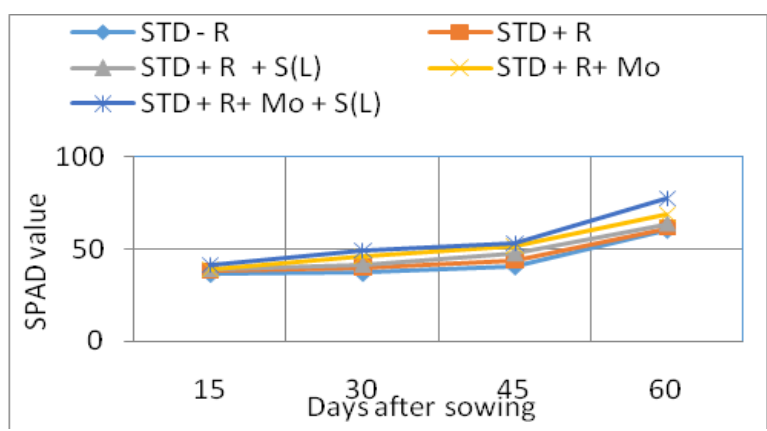

(b) Black gram

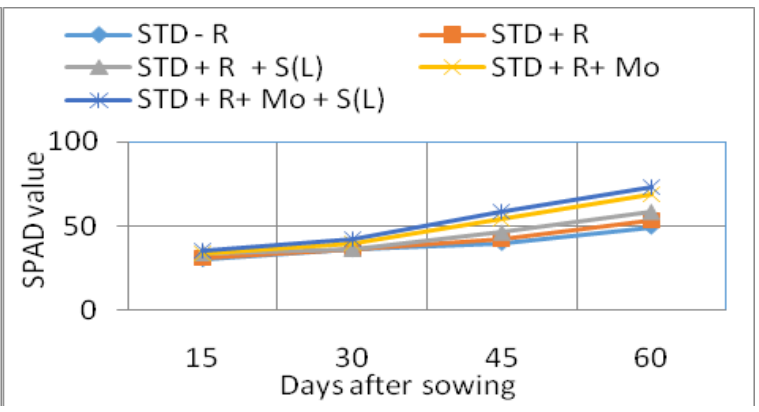

(d) Horse gram

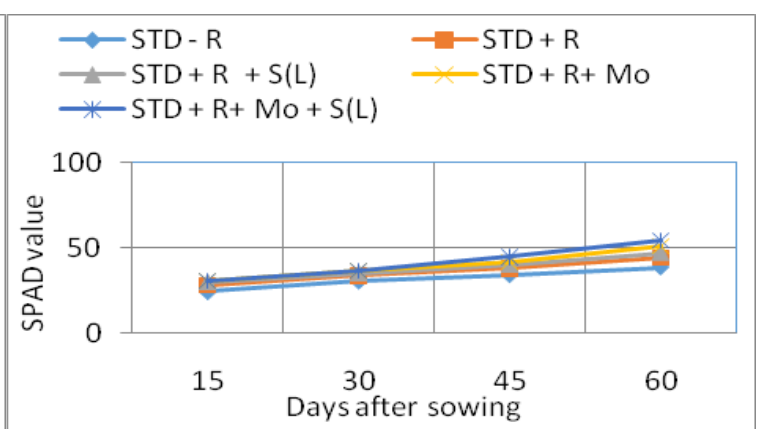


The $\mathrm{N}$ content in nodules of cowpea and black gram were at par but significantly higher in green gram and further with horse gram. Seed inoculation with Rhizobium alone increased it by 21 per cent over no inoculation, combining of seed coating with lime by further 25 per cent, or combining Mo seed treatment by 83 per cent but combination of both by 87 per cent compared over Rhizobium seed inoculation. All these emphasis the necessity of the POPs in improving $\mathrm{N}_{2}$ fixing abilities in pulse crops.

The amount of nodule $\mathrm{N}$ per plant (Table 1) in different pulse crops ranged from 2.14 to $12.25 \mathrm{mg}$ plant $^{-1}$, highest with green gram and lowest with horse gram crop. Seed inoculation with Rhizobium increased it by 78 per cent over no inoculation. Combining seed coating with lime further, increased it by 50 per cent, but combining Mo seed treatment had far more influence i.e., 156 per cent increase. Integration of both of these practices increased nodule $\mathrm{N}$ plant ${ }^{-1}$ by 163 per cent over only Rhizobium inoculation. This emphasized the usefulness of the POPs in influencing pulse crop efficiencies. Liming and molybdenum had a positive effect on growth, yield, $\mathrm{N}$ content of foliage and roots and nodule formation in legume crops (Togay et al., 2008)

\section{Green gram equivalent yield of pulse crops}

The green gram equivalent yield of pulse crops varied between 240 and $763.6 \mathrm{~kg} \mathrm{ha}^{-1}$, lowest with horse gram and highest with cowpea. Based on productivity different pulse crops can be arranged in the order: cowpea > black gram $>$ green gram $>$ horse gram (Table 2 ). With the application of soil test based fertilizers, the mean productivity of four pulse crops was $336 \mathrm{~kg} \mathrm{ha}^{-1}$ (green gram equivalent yield) without any amelioration measure. On an average 16 per cent yield could be increased with adoption of seed inoculation with suitable Rhizobium. Asokan et al., (2000) found that seed inoculation with bio fertilizers supplied the bioactive compounds such as vitamins, hormones, enzymes and essential nutrients such as nitrogen, phosphorus and molybdenum favorably influenced the plant vigor, morphology and metabolic processes, which ultimately enhanced the pods per plant and total yield. Combining acid soil ameliorative measure by seed coating with lime could increase the yield by 14 per cent. In an experiment done by Hartley et al., (2004), lime supply increased nodulation and yield of Serra Della. The beneficial effects of liming on nodulation and plant growth most likely resulted from the enhanced conditions for seedling growth and nodulation. Likewise combining Mo seed treatment with Rhizobium inoculation was very much effective in increasing crop productivity (45 per cent higher yield). Various studies have reported that application of Mo enhances the yield in crops that grow in deficient soil (Liu, 2001; Min et al., 2005; Xue-Cheng et al., 2006). Sable et al., (2000) reported significant influence of seed inoculation with Rhizobium and molybdenum on soybean roots growth and yield. Bambara and Ndakidemi (2010) demonstrated that the Mo is less available in acidic soil and foliar application can overcome this problem. Although foliar application of $\mathrm{Mo}$ is beneficial, but the seed and soil applications remain effective for longer period under normal conditions. As the soil was deficient in Mo, its supplementation encouraged $\mathrm{N}_{2}$ fixation and imparted other beneficial effects on crop growth. Combination of all the three POPs, seed coating with lime, Rhizobium seed inoculation and Mo seed treatment helped doubling the productivity from $336 \mathrm{~kg} \mathrm{ha}^{-1}$ to $630 \mathrm{~kg} \mathrm{ha}^{-1}$ even if in the problematic soil.

Lime coating of seed increased the soil $\mathrm{pH}$ from initial extremely acidic soil $\mathrm{pH}$ (4.49) to moderate range ( $\mathrm{pH} 5.1$ to 5.5), and thus 
indirectly favoured creation of more suitable medium for nutrient uptake by legumes. This condition creates a conducive soil environment for the crops that enables efficient use of both organic and inorganic nutrients which ultimately resulted in better performance of yield and yield components like nodulation in legumes. The results of this study also highlighted the role of molybdenum as seed treatment for improving the yield and other parameters like nodulation and nodular nitrogen content. However, integrated use of lime seed coating together with recommended doses of Rhizobium and ammonium molybdate significantly affected agronomic parameters (chlorophyll content, leaf area, plant height, number of nodules, grain yield).The findings of the study revealed that the growth, and yield of legumes responded significantly to the integrated application of package of practices, and the highest yield (630 Kg ha-1) was obtained with integrated use of lime seed coating together with recommended doses of Rhizobium and ammonium molybdate.

\section{References}

AOAC.1960. Official Methods of Analysis of the Association of official Agricultural chemists, $9^{\text {th }}$ Edn. Pp. 12-3. Association of official Agricultural chemists, Washington, DC.

Asokan, R., Mohandas, S., Anand, L., 2000. Biofertilizers and biopesticides for horticultural crops. Indian Horticult. 2, 4452.

Bambara, S. and P.A. Ndakidemi. 2010. The potential roles of lime and Molybdenum on the growth, nitrogen fixation and assimilation of metabolites in nodulated legume: A special reference to Phaseolus vulgaris L. Afr. J. Biotechnol., 8(17): 24822489.

Glubaiak, E.S. 2008. The influence of soil reaction on the effects of molybdenum foliar fertilization of oilseed rape. J.Elementol., 13(4): 647-654.
Gomez KA and Gomez, A>A. 1976. Statistical procedures for Agricultural research with emphasis on rice. IRRI. Los Banos, Laguma, Philippines.

Hansch, R., Mendel, R.R. 2009. Physiological functions of mineral micronutrients $(\mathrm{Cu}$, $\mathrm{Zn}, \mathrm{Mn}, \mathrm{Fe}, \mathrm{Ni}, \mathrm{Mo}, \mathrm{B}, \mathrm{Cl})$. Curr. Opin. Plant Biol. 12, 259-266.

Hartley E, Greg-Gemell L, Herridge FD (2004). Lime pelleting inoculation serradella (Ornithopus spp.) increases nodulation and yield. Soil Biol. Biochem. 36:1289-1294.

Jackson, M.L., 1973. Soil Chemical Analysis. Prentice Hall of India Pvt. Ltd, New Delhi, India.

Kumar M., Hazarika S, Chaudhury BU and Ramesh T. 2012. Liming and integrated nutrient management for enhancing maize productivity on acidic soils of north-east India. Indian journal of Hill Farming 28.

Lambers H, Chapin FS, Pons TL (1998). Plant Physiology Ecology Springer. New York. $540 \mathrm{p}$.

Liu P (2001). The research development of molybdenum and boron nutrition in soybean. China Agric. Sci. Bulletin. 17:4144

Liu P (2002) Effects of the stress of molybdenum on plants and the interaction between molybdenum and other element. Agrienvironmental Protection. 21:276- 278.

Lucrecia M, Ramos G, Boddey RM (1987). Yield and nodulation of Phaseolus Vulgaris and the competitivity of an introduced Rhizobium strain: Effects of lime, mulch and repeated cropping. Soil Biol. Biochem. 19:171-177.

Majhi R, Pattanayak SK. 2015. Encapsulation of green gram seed with lime influencing its productivity and quality. P.G thesis submitted to OUAT.

Marschner H (1995). Mineral Nutrition of higher plants. Academic Press, San Diego.

Mcbride MB (2005). Molybdenum and copper uptake by forage grasses and legumes grown on a metal-contaminated sludge site. Commun Soil Sci. Plant Anal.36:24892501.

Min Y, Yue-Jin C, Hong-Dong X, Hui-Zhen W, Fang W, Xiu-Hua S (2005). Influences of Boron and Molybdenum on Active Oxygen 
Species in Turfgrass Seashore Paspalum under low temperature. Acta Agron. Sin.31:755-759.

Page, A.L., 1982. Methods of Soil Analysis, Part II, Chemical and Microbiological Properties. American Society of Agronomy, Madison, USA.

Pati S, Pattanayak SK. 2016. Encapsulation of green gram seed with lime influencing its productivity and quality. P.G thesis submitted to OUAT.

Pattanayak SK and Sarkar A. 2016. Sustainable management of Acid Soils: Technologies and their Transfer. Indian Journal of Fertilizers, Vol. 12(7), pp.16-24 \& 3

Pattanayak SK, Dash D, Jena MK and Nayak RK. 2000. Seed treatment of green gram with Mo and Co. Effect on nodulation, biomass production and $\mathrm{N}$ uptake in an acid soil. Journal of the Indian Society of Soil Science, 48(4):769-773

Pattanayak SK. 2016. Biological Nitrogen Fixation -Status Potential and Prospects in Supplementing Nitrogen needs of the crops. Indian Journal of Fertilizer, 12(4), pp.94103

Pattanayak SKand Rao DLN. 2014. Technical bulletin on "Biofertilizers improve Triable Livelihood in Odisha. AINP on SoilBiodiversity-Biofertilizers (ICAR), Orissa University of Agriculture and Technology, Bhubaneswar, Odisha, pp.1-27

Rahman, M.M., Bhuiyan, M.M.H., Sutradhar, G.N.C., Rahman, M. M., Paul, A.K. 2008. Effect of phosphorus, molybdenum and Rhizobium inoculation on yield and yield attributes of mungbean. Int. J. Sustain. Crop Prod. 3, 26-33.

Reddy KJ, Munn LC, Wang L. 1997. Chemistry and mineralogy of molybdenum in soils. In: Gupta UC, ed. Molybdenum in agriculture. Cambridge: Cambridge University Press.

Sable, S., Sontakey, P.Y., Nair, B., Manapure, P., Deotale, R.D., 2000. Influence of seed inoculation with Rhizobium and molybdenum on soybean roots. J. Soils Crops, 10 (2), 126-130.

Subasinghe, S., Dayatilake, G.A., Senaratne, R., 2003. Effect of B, Co and Mo on nodulation, growth and yield of cowpea (Vigna unguiculata). Trop. Agric. Res. Ext. 6, 108-112.

Tandon, H.L.S., 1999. Methods of Analysis of Soil, Plants, Waters and Fertilizers. Fertiliser Development and Consultation Organization, New Delhi, India.

Togay N, Togay Y, Cimrin KM, Turan M 2008. Effect of Rhizobium inoculation, sulfur and phosphorus application on yield, yield components and nutrient uptake in chick pea (Cicer aretinum L.). African Journal of Biotechnology. 7(6): 776-782.

White PJ, Broadley MR (2003). Calcium in plants. Ann. Botany. 92:487-511.

Xue-Cheng S, Cheng-Xiao H, Qi-Lin T, QiaoQiao G.2006. Effects of molybdenum on photosynthetic characteristics in winter wheat under low temperature stress. Acta Agron. Sinica.32:1418-1422.

\section{How to cite this article:}

Purbasha P. Padhi and Pattanayak, S.K. 2018. Effect of Lime Coating and Molybdenum Seed Treatment on Nodulation, Growth and Yield of Different Pulses Grown in Alfisols. Int.J.Curr.Microbiol.App.Sci. 7(02): 1417-1426. doi: https://doi.org/10.20546/ijcmas.2018.702.171 